\title{
PReS-FINAL-1003: Intrinsic cd4 and cd8 effector t cell resistance to suppression in the synovial fluid of juvenile idiopathic arthritis patients
}

\author{
A Petrelli, EJ Wehrens, BJ Prakken, F van Wijk \\ From 20th Pediatric Rheumatology European Society (PReS) Congress \\ Ljubljana, Slovenia. 25-29 September 2013
}

\section{Introduction}

Autoimmune diseases are characterized by an imbalance between regulatory $\mathrm{T}$ cells (Treg) and effector $\mathrm{T}$ cells (Teff) both in terms of number and function. Our group previously showed that Teff from the site of inflammation (i.e. synovial fluid, SF) of patients affected by Juvenile Idiopathic Arthritis (JIA) are resistant to autologous Treg-mediated suppression irrespective of the source of Tregs (SF or peripheral blood(PB)-derived). However, it is still unclear whether resistance to suppression is an intrinsic characteristic of SF-derived Teff or it is induced/ maintained by local pro-inflammatory antigen presenting cells (APC).

\section{Objectives}

The aim of this study was to elucidate whether $\mathrm{T}$ cells from the SF are intrinsically resistant to Treg-mediated suppression.

\section{Methods}

A suppression assay of Cell Trace Violet (CtV)-labeled CD4+CD25- and CD8+ sorted Teff from PB and SF of JIA patients was performed by using anti-CD3 mAb (1.5 $\mu \mathrm{g} / \mathrm{ml}$ ) plus autologous CD3- cells or anti-CD2/CD3/ $\mathrm{CD} 28$ beads as stimulators. CtV dilution was used to measure $\mathrm{T}$ cell proliferation.

\section{Results}

CD4+ and CD8+ T cells from the SF showed enhanced proliferation compared to the $\mathrm{PB}$. When stimulated with beads, Teff from SF were suppressed by Treg from the same site to a lesser extent then PB Teff. When Teff from

\footnotetext{
Ped. Immunology, Laboratory of Translational Immunology, UMC Utrecht,
} Utrecht, The Netherlands

\section{and take full advantage of:}

- Convenient online submission

- Thorough peer review

- No space constraints or color figure charges

- Immediate publication on acceptance

- Inclusion in PubMed, CAS, Scopus and Google Scholar

- Research which is freely available for redistribution 